\title{
EVALUATION OF SERUM HIGH SENSITIVITY C - REACTIVE PROTEIN (hs-CRP) IN TYPE-2 DIABETIC PATIENT
}

\author{
A.K.M. FAZLUL HAQUE ${ }^{1}$, A.R.M.SAIFUDDIN EKRAM ${ }^{2}$, QUAZI TARIKUL ISLAM ${ }^{3}$, MD.SARWARJAHAN ${ }^{4}$, \\ MD. ZAHIRUL HAQUE ${ }^{5}$
}

\begin{abstract}
Type-2 diabetes may remain in subclinical form for years before diagnosis. This quiescence of type-2 diabetes is a great concern for health care providers.

The earliest change of the type- 2 diabetes is the insulin resistance, which is associated with the increased macrovascular risk due to induction of chronic inflammation in the vessels of the body which leads to atherosclerotic change in the vessels.

High sensitivity $C R P(h s-C R P)$ is the measure of $C$-reactive protein with greater accuracy and the lower limit of its assay is .01 mg/L which is more than 100 times as sensitive as the usual CRP measurement (lower limit $5 \mathrm{mg} / \mathrm{L}$ ). The median level of hs-CRP from blood samples of apparent healthy subjects is $0.8 \mathrm{mg} / \mathrm{L}$. For this, physician uses the hs-CRP parameter as a marker of chronic inflammation in apparently normal healthy individuals, specially for the assessment of atherosclerosis, which is a chronic inflammatory procedure from the very beginning, in type- 2 diabetic, obese and hypertensive patients. This vascular atherosclerosis assessment help them to calculate the cardiovascular as well as cerebrovascular risk of those patients. To help the type-2 diabetic patients from the very begining in respect of the prognostic view of the macrovascular risk, estimations of serum hs-CRP in the early stage of these patient may be a enthusiastic one. This descriptive study was carried out by choosing 70 diabetic patient who had no other comorbidity or any complications of diabetes and 35 healthy subjects who were neither diabetic nor had any diseases. Both the groups were non-smoker and non-alcoholic and non-hypertensive, hs-CRP

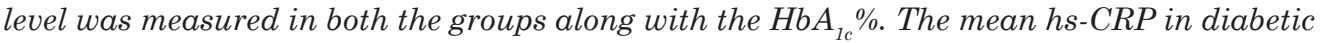
group was $1.13 \mathrm{mg} / \mathrm{L}$ and in normal healthy subjects was $0.39 \mathrm{mg} / \mathrm{L}$. This higher level of mean hs-CRP $(1.13 \mathrm{mg} / L)$ in diabetic patients is statisticaly significant $(P<0.01)$ compared with that of the normal healthy subjects mean $h s-C R P(0.39 \mathrm{mg} / L)$. This mean level of hs-CRP in normal healthy subjects was below the lower level of cardiovascular risk $(1 \mathrm{mg} / \mathrm{L})$.
\end{abstract}

Keyword: High sensitivity CRP, C-reactive protein, diabetes

\section{Introduction}

Diabetes is world-wide in distribution and the incidence of both type- 1 and type- 2 diabetes is rising. The prevalence of known diabetes in patients is around $2-3 \%$ but is higher in the middle and fareast (e.g. $12 \%$ in the Indian subcontinents). ${ }^{1}$ The prevalence of diabetes is up to 4-6 fold higher in South Asians immigrant in UK compared with European
Caucasians, and a high prevalence is also noted in urban dwelling South Asians. ${ }^{2}$ Diabetes, hyperinsulinemia and coronary risk factors are more prevalent in Bangladeshis compared with other South Asian groups (Indian, Pakistani) settled in United Kingdom. ${ }^{3}$ It has also been reported that Bangladeshis among the entire South Asian immigrants had highest mortality and attack rate

1. Medical Officer, Asthma Centre, NIDCH, Mohakhali, Dhaka.

2. Professor, Department of Medicine, Rajshahi Medical College, Bangladesh.

3. Professor, Department of Medicine, Dhaka Medical College, Bangladesh.

4. Lecturer, Community Medicine, Rajshahi Medical College, Bangladesh.

5. Assistant Professor, Department of Medicine, Rajshahi Medical College, Bangladesh.

Correspondence: Dr. A.K.M. Fazlul Haque, Registrar (Medicine), Rajshahi Medical College, Rajshahi-6000, Bangladesh. E-mail: rubel6000@yahoo.com 
from coronary heart disease. ${ }^{4}$ It is now clear that insulin resistance is the primary event and it is followed by increasing degree of $\beta$-cell dysfunction, in type- 2 diabetes. ${ }^{5}$ Insulin resistance often accompany excess visceral adiposity, dyslipidemia, hypertension, impaired fibrinolysis, increased platelet aggregation, vascular inflammation, endothelial dysfunction and premature atherosclerosis. ${ }^{6}$ All these events may herald the thrombo-embolic manifestations in the body. Certain protein known collectively as the acute phase response are produced early in inflammation mainly by the liver. The best known of these are C-reactive protein and mannose binding protein. C-reactive protein (CRP) is a non-specific indicator of inflammation and the medical importance of CRP is that an elevated CRP appears to be better predictor of heart attack risk than an elevated cholesterol level. ${ }^{7}$ The highest correlation between CRP and body mass index (BMI) was found, followed by the index of insulin resistance, fasting insulin and insulin sensitivity. ${ }^{8}$ It was established that in persons with higher levels of CRP the possibility of diabetes to develop for the period of 3-4 years is greater than those with the normal values for CRP. ${ }^{9}$

It was found that CRP is directly associated in atherosclerotic plaque formation. CRP induces the adhesion molecule expression in endothelial cells, stimulates monocyte chemo-attractant protein-1 production and induces complement activations. Binding to oxidized LDL-particles, CRP stimulates macrophage digestion. ${ }^{10}$

hs-CRP (high sensitivity C-reactive protein) is the measurement of CRP level with greater accuracy. The lower limit of its measurement is $0.01 \mathrm{mg} / \mathrm{L}$ and the measurement is more than 100 times as sensitive as the usual CRP measurement (lower limit $5 \mathrm{mg} / \mathrm{L})$. The median level of hs-CRP from blood samples of apparently healthy donors (median age of 32 years) is $0.3 \mathrm{mg} / \mathrm{L} .{ }^{11}$ Although hs-CRP levels $>10 \mathrm{mg} / \mathrm{L}$ are often found in systemic inflammation. Levels $<1,1-3$ and $>3 \mathrm{mg} / \mathrm{L}$ respectively identify patients at low, intermediate and high risk for future cardiovascular events. The prognostic value of CRP level is independent and additive to lipid values. ${ }^{12}$

As Bangladeshi people are more susceptible to type2 diabetes related macro vascular complications like coronary artery disease, serum hs-CRP may be of great value.

\section{Materials and Methods}

This study was conducted in the outpatient department of Rajshahi diabetic association hospital and in the Rajshahi medical college campus from January 2007 to June 2007. Laboratory investigations were done in Rajshahi diabetic association hospital laboratory and the local privately owned laboratory at Laxmipur in Rajshahi. 70 type2 diabetic patients ( 45 male 25 female). These selected patients were less than 2 years duration from diagnosis of diabetes, had no complications of type- 2 diabetes, no other co-morbid diseases. They were non-alcoholics, non-smokers, non-hypertensive and had no evidence of kidney and liver disease, their BMI was $<30 \mathrm{Kg} / \mathrm{M}^{2}$ and waist-to-hip ratio was also $<1$ in man $\&<0.9$ in female. The mean (40) age of the patients was $46.54 \pm 6.5$ years (range $40-60$ years) in male and $47.97 \pm 45$ years (range $40-60$ years) in female. The age and all other criteria matched 35 (20 male and 15 female) healthy control group who were chosen to compare with the diabetic patients. Prior to inclusion into the study, written informed consent was taken from each subject. Purposive method was followed. The sample was collected by the investigator himself. Blood samples were taken from each patient for hs-CRP, RBS and $\mathrm{HbA}_{1 \mathrm{c}}$. With all aseptic precaution $10 \mathrm{cc}$ of blood were collected from the antecubital vein using a disposable plastic syringe. Serum was separated by centrifugations (10 minutes) at the rate of $2000 \mathrm{rpm}$ at a room temperature immediately after the blood was allowed to clot for 30 minutes. Separated serum was allocated in different appended for subsequent analysis. Reagent for hs-CRP was collected from Tulip Diagnostic (P) Ltd, Goa, India through a local company. Test for serum hs-CRP was done in local standard laboratories with the help of experts, from the local company. Plasma glucose and glycosylated haemoglobin was estimated in the Rajshahi Diabetic Associations laboratories. Data analysis included some clinical and epidemiological data to identify the clinical characteristics of the patients and the data of the patients was compared with the normal healthy people. The data was analyzed with the help of SPSS soft ware programme expressed as Mean \pm SD (Standard deviation). Z-test, was done to see the significance of difference of different parameters of diabetic people and normal healthy people. A P-value of $<0.05$ was considered as significant. 


\section{Results}

The present study was intended to asses the difference of hs-CRP level between type- 2 diabetic patients and normal healthy people (Table I).

The mean age of the type-2 diabetic patients and normal healthy people was 46.54 year (standard deviation \pm 6.5 ) and 47.97 (standard deviation \pm 5.4) year respectively i.e. the two groups were well matched regarding age.

The fasting plasma glucose of type-2 patients was $8.79 \pm 1.45$ (Mean \pm standard deviation) $\mathrm{mmol} / \mathrm{L}$, whereas the fasting plasma glucose level of normal healthy people was $5.32 \pm 0.37$ (Mean \pm standard deviation).

$\mathrm{HbA}_{1 \mathrm{c}} \%$ (Mean \pm standard deviation) of normal healthy people was $5.61 \pm 1.12$ and type- 2 diabetic patients was $9.86 \pm 3.10$.

hs-CRP (mg/L) level of normal healthy people and diabetic patients were $0.39( \pm 0.24)$ and $1.13( \pm 1.58)$ respectively.

The difference in the plasma hs-CRP level between normal people and type- 2 diabetic patients are significant $(\mathrm{P}<0.01)$.

Table I

Distribution of age, glycemic status and hs-CRP level among the normal people and type-2 diabetic patients

\begin{tabular}{|c|c|c|c|}
\hline $\begin{array}{l}\text { Respondent's } \\
\text { characteristic }\end{array}$ & $\begin{array}{c}\text { Normal healthy } \\
\text { peoplen }=35\end{array}$ & $\begin{array}{c}\text { Type- } 2 \text { diabetic } \\
\text { patients } n=70\end{array}$ & $\begin{array}{c}\mathrm{P}- \\
\text { value }\end{array}$ \\
\hline Age & 47.97 & 46.54 & $>0.05$ \\
\hline$($ mean $\pm S D)$ & \pm 5.448 & \pm 6.505 & \\
\hline $\mathrm{FBS} \mathrm{mmol} / \mathrm{L}$ & 5.6171 & 8.7914 & $<0.05$ \\
\hline$($ mean $\pm S D)$ & \pm 0.3737 & \pm 1.453 & \\
\hline $\mathrm{HbA}_{1 \mathrm{c}} \%$ & 5.6129 & 9.8629 & $<0.05$ \\
\hline$(\operatorname{mean} \pm \mathrm{SD})$ & \pm 1.11963 & \pm 3.1096 & \\
\hline hs-CRP mg/L & 0.3883 & 1.1257 & $<0.01$ \\
\hline$($ mean $\pm S D)$ & \pm 0.2434 & \pm 1.583 & \\
\hline
\end{tabular}

Data are presented here as mean and $\pm \mathrm{SD}, \mathrm{n}=$ number of subject, hs-CRP=high sensitivity C-reactive protein, $\mathrm{HbA}_{1 \mathrm{c}} \%=$ glycosylated haemoglobin $\%, \mathrm{SD}=$ Standard deviation.

Data were analysed using Z-test and P-value for hs$\mathrm{CRP}$ was significantly higher in diabetic patients in comparison to normal people $(\mathrm{P}<0.01)$.

\section{Discussion}

The purpose of this study was to assess the plasma hs-CRP level of type-2 diabetic patients and normal healthy people of similar age distribution. The people of both group were non-smoker, non-alcoholic and non-hypertensive and the diabetic patients had no complications of diabetes.

There is not enough data of serum hs-CRP level of our normal non-diabetic people, but in some studies of western authors it has been shown that Asian people has comparatively higher level of CRP. ${ }^{13,14}$

Chamber JC et al. in the year 2001 measured serum C- reactive protein (CRP) and conventional coronary heart disease (CHD) risk factors in 1025 healthy male subjects (518 Indian Asian and 507 European Whites) aged about $35-60$ years. ${ }^{15}$ The mean CRP concentration was $17 \%$ higher in Indian Asian compared with European whites.

Saijo et al. showed in their study in year 2004 that the serum CRP concentration was lower in healthy Japanese subject $0.52 \mathrm{mg} / \mathrm{L}$. than in diabetic patients $(0.97 \mathrm{mg} / \mathrm{L}){ }^{16}$

In a study by Graham T.E et al. showed in 2006 that subjects with diabetes-2 had higher baseline levels of C-reactive protein, interleukin- 6 and free fatty acids than those with impaired glucose tolerance. ${ }^{17}$

Y Guoyne at al. showed in the year 2006 that in comparison with normal control(healthy people) serum hs-CRP was significantly increased in impaired glucose tolerance (IGT) and type-2 diabetes mellitus group $(\mathrm{P}<0.001)$, although there was no significance between the two groups. ${ }^{18}$

In a study in Bangladesh in 2007 by Rosy N showed that hs-CRP wasd significantly higher in Gestational diabetes mellitus (GDM) group $(9.56 \mathrm{mg} / \mathrm{L})$ than to control (normal pregnant group, $2.19 \mathrm{mg} / \mathrm{L}$ ). ${ }^{19}$

In our study mean hs-CRP level of healthy people were found $0.39 \mathrm{mg} / \mathrm{L}$ which was within normal range and below the level of mild risk for cardiovascular disease $(<1 \mathrm{mg} / \mathrm{L}) .{ }^{12}$ Besides these in our study we have found that mean hs-CRP of type2 diabetic patients was $1.13 \mathrm{mg} / \mathrm{L}$ which was significantly higher than that of the normal healthy people $(0.39 \mathrm{mg} / \mathrm{h})[\mathrm{P}<0.01)]$. Plasma hs-CRP level in type-2 diabetic patients was about 3 times higher than normal people. 


\section{References}

1. Frier BM, Fiskar BM. Diabetes Mellitus. In: Boon NA, Colladge NR, Walker BR, Hunter JA, eds. Davidson's Principles and Practice of Medicine, $20^{\text {th }}$ ed. London: Churchill Livingstone, Elsevier, 2006: 805-848.

2. Forouhi NG, Warcham NJ. Epidemiology of diabetes. Medicine International 2006; 06 (1): 5859 .

3. NcKeigue PM, Miller GJ, Marmot MG. Coronary heart disease in South Asians overseas-a review. J Clin Epidemiol 1989; 42: 597-609.

4. McKeigue PM, Marmot MG, Syndercombe CYD, et al. Diabetes hyperinsulinemia and coronary risk factors in Bangladeshis in East London. Br Heart J 1988; 60: 390-396.

5. Abbas AK, Maitra A. The endocrine Pancreas. In: Kumar V, Abbas AK, Fausto N, eds. Robbins and Cotran Pathologic Basis of Disease, $7^{\text {th }}$ ed. New Delhi: Elsevier, 2005: 1189-1207.

6. Fonseca VA. Management of diabetes mellitus and insulin resistance in patients with cardiovascular disease. Am J Cardiol 2003; 92 (suppl): 501-601.

7. Levinson W. Medical Microbiology and Immunology, $8^{\text {th }}$ ed. New York: McGraw Hill, 2004: 113.

8. Festa A, D'Agostino R JR, Howard G, et al. Chronic subclinical inflammation as part of the insulin resistance syndrome: the Insulin Resistance Atherosclerosis Study (IRAS). Circulation 2000; 102: $42-47$.

9. Brazilay JI, Abraham L, Hecbert SR, et al. The relation of markers of inflammation to the development of glucose disorders in the elderly. Diabetes 2001; 50: 2384-2389.

10. Chang MK, Binder CJ, Fowler SE, et al. C-reactive protein binds to both oxidized LDL and apoptotic cells through recognition of a common ligand:
Phosphorilcholine of oxidized phospholipids. Diabetes 2002; 99: 13043-13048.

11. Tajiri Y, Minura K, Umeda F. High-sensitivity Creactive protein in Japanese patients with type-2 diabetes. Obesity Research 2005; 13: 1810-1816.

12. Massie BM, Granger BC. Heart. In: Tierney LM Jr., McPhee SJ, Papadakis MA, eds. Current Medical diagnosis and Treatment, $44^{\text {th }}$ ed. New York: McGraw Hill, 2005:308-403.

13. Ikonomova K. Inflammation and Metabolic syndrome. Turkish Journal of Endocrinology and Metabolism 2004; 8 (3): 68-69.

14. McKeigue PM, Bela S, Marmot MG. Relation of central obesity and insulin resistance with high diabetes prevalence and cardiovascular risk in South Asians. Lancet 1991; 337: 382-386.

15. Chambers JC, Eda S, Basset P, Spencer A, et al. Creactive protein, insulin resistance, central obesity and coronary heart disease risk in Indian Asians from the United Kingdom compared European whites. Circulation 2001; 104:145- 150.

16. Saijo Y, Kiyota N, Kawasaki Y, et al. Relationship between C-reactive protein and Visceral adipose tissue in healthy Japanese subject. Diabetes Metab 2004; 6:249-258.

17. Graham TE, Yang Q, Biuher M, et al. Retinal Binding protein for and insulin resistance in lean, obese, and diabetic subjects. N Engl J Med. 2006; 354: 2552-63.

18. Yuan G, Zhon L, Taug J, et al. Serum CRP levels are equally elevated in newly diagnosed type 2 diabetes and impaired glucose tolerance and related to adiponectin levels and insulin sensitivity. Diabetes Res Clin Pract 2006; 72(3): 244-250.

19. Rosy N. Association of high-sensitive C-reactive protein with the glycemic status in gestational Diabetes mellitus (thesis). Dhaka: BIRDEM, 2007. 